\title{
Guides to This Book
}

Because the improvements planned along the $\mathrm{I}-287$ corridor were poised to reshape the entire New York metropolitan area, hundreds of elected officials, bureaucrats, business leaders, grassroots activists, and everyday citizens participated in the planning process. The following figures and tables provide a quick reference for readers to recall the major players, institutions, and events.

- Table G.r lists key organizations.

- Table G.2 lists key players in the planning process.

- Figure G.I shows the tristate New York metropolitan area. (The I-287 corridor in New York runs across Rockland and Westchester Counties.)

- Figure G.2 shows the east-west I-287 corridor as well as the existing rail lines that connect the corridor with northern New Jersey (west of the Hudson River) and Manhattan (east of the Hudson River).

- Figure G.3 provides a timeline of key events along with the tenure of six governors and three Westchester County executives.

\section{Table G.1}

\section{Key Organizations}

\begin{tabular}{ll}
\hline Organization & \multicolumn{1}{c}{ Role } \\
\hline $\begin{array}{l}\text { Federated Conservationists of } \\
\text { Westchester County }\end{array}$ & Coalition of Westchester County environmental groups. \\
$\begin{array}{ll}\text { New York State Department of } \\
\text { Transportation (NYS DOT) }\end{array}$ & $\begin{array}{l}\text { State agency responsible for most of New York's } \\
\text { highways. }\end{array}$ \\
\hline
\end{tabular}

(continued) 
Table G.1 (continued)

Metropolitan Transportation Authority (MTA)

Metro-North Railroad

New York State (NYS) Thruway Authority

New York Metropolitan

Transportation Council

Port Authority of New York and New Jersey ("Port Authority")

Regional Plan Association
Largest transportation provider in the U.S., whose subsidiaries include Long Island Rail Road, MetroNorth Railroad, New York City Transit, and MTA Bridges and Tunnels.

Subsidiary of the Metropolitan Transportation Authority that provides passenger railroad services to New York City and its northern suburbs.

Owner and operator of the New York State Thruway, including the Tappan Zee Bridge.

Metropolitan planning organization that programs all federal transportation funds for projects in New York City, Long Island, and Rockland, Westchester, and Putnam Counties.

Bi-state transportation agency responsible for Hudson River crossings, airports, and transit services. It was originally known as the Port of New York Authority.

Independent, not-for-profit regional planning organization that recommends improvements for the New York metropolitan area.

Tri-State Transportation Campaign Advocacy group established in the 1990s to reduce car ("Tri-State") dependency in New York, New Jersey, and Connecticut.

U.S. Department of Transportation Provides federal transportation funding to states and localities. Its subsidiaries include the Federal Transit Administration and the Federal Highway Administration.

Westchester County Association Westchester County business organization.

\section{Table G.2}

\section{Key Players}

\section{Name}

Michael Anderso

Janine Bauer

Andrew Cuomo

George Case

Robert Conway

Virgil Conway

Robert Dennison
Position

NYS DOT engineer and manager of the I-287 / Tappan Zee project

Tri-State Transportation Campaign executive director

Governor of New York

Federated Conservationists of Westchester County president

AKRF (environmental consulting firm) engineer

MTA chairman, I-287 Task Force chairman, and NYS Thruway

Authority board member

NYS DOT regional director and chief engineer 
Table G.2 (continued)

\begin{tabular}{|c|c|}
\hline Thomas Dewey & Governor of New York \\
\hline Drew Fixell & Tarrytown mayor \\
\hline Tim Gilchrist & $\begin{array}{l}\text { NYS DOT executive and senior advisor to Governors Spitzer and } \\
\text { Paterson }\end{array}$ \\
\hline Janet Mainiero & Metro-North planner \\
\hline Maureen Morgan & $\begin{array}{l}\text { Federated Conservationists of Westchester County president and } \\
\text { Westchester County Chamber of Commerce official }\end{array}$ \\
\hline Andrew O'Rourke & Westchester County Executive \\
\hline George Pataki & State legislator and governor of New York \\
\hline David Paterson & Lieutenant governor and governor of New York \\
\hline Ross Pepe & $\begin{array}{l}\text { New York Construction Industry Council of Westchester and Hudson } \\
\text { Valley president }\end{array}$ \\
\hline Howard Permut & $\begin{array}{l}\text { Metro-North's planning director, vice president, senior vice president, } \\
\text { and president }\end{array}$ \\
\hline Rich Peters & NYS DOT engineer \\
\hline John Platt & NYS Thruway Authority executive director \\
\hline Richard Ravitch & MTA chairman and Governor Paterson's lieutenant governor \\
\hline Al Samuels & Rockland Business Association president \\
\hline Sy Schulman & $\begin{array}{l}\text { Westchester County planning commissioner and president of the } \\
\text { Westchester County Association }\end{array}$ \\
\hline John Shafer & NYS Thruway Authority executive director \\
\hline Kate Slevin & Tri-State Transportation Campaign executive director \\
\hline Lou Tomson & $\begin{array}{l}\text { NYS Thruway Authority chairman and Governor Pataki’s deputy } \\
\text { secretary }\end{array}$ \\
\hline Jim Tripp & $\begin{array}{l}\text { Environmental Defense Fund attorney and Tri-State Transportation } \\
\text { Campaign founder }\end{array}$ \\
\hline Scott Vanderhoef & Rockland County Executive \\
\hline Chris Waite & NYS Thruway Authority chief engineer \\
\hline Robert Weinberg & Westchester County commercial real estate developer \\
\hline Franklin E. White & NYS DOT Commissioner \\
\hline Jeff Zupan & Regional Plan Association senior fellow \\
\hline
\end{tabular}




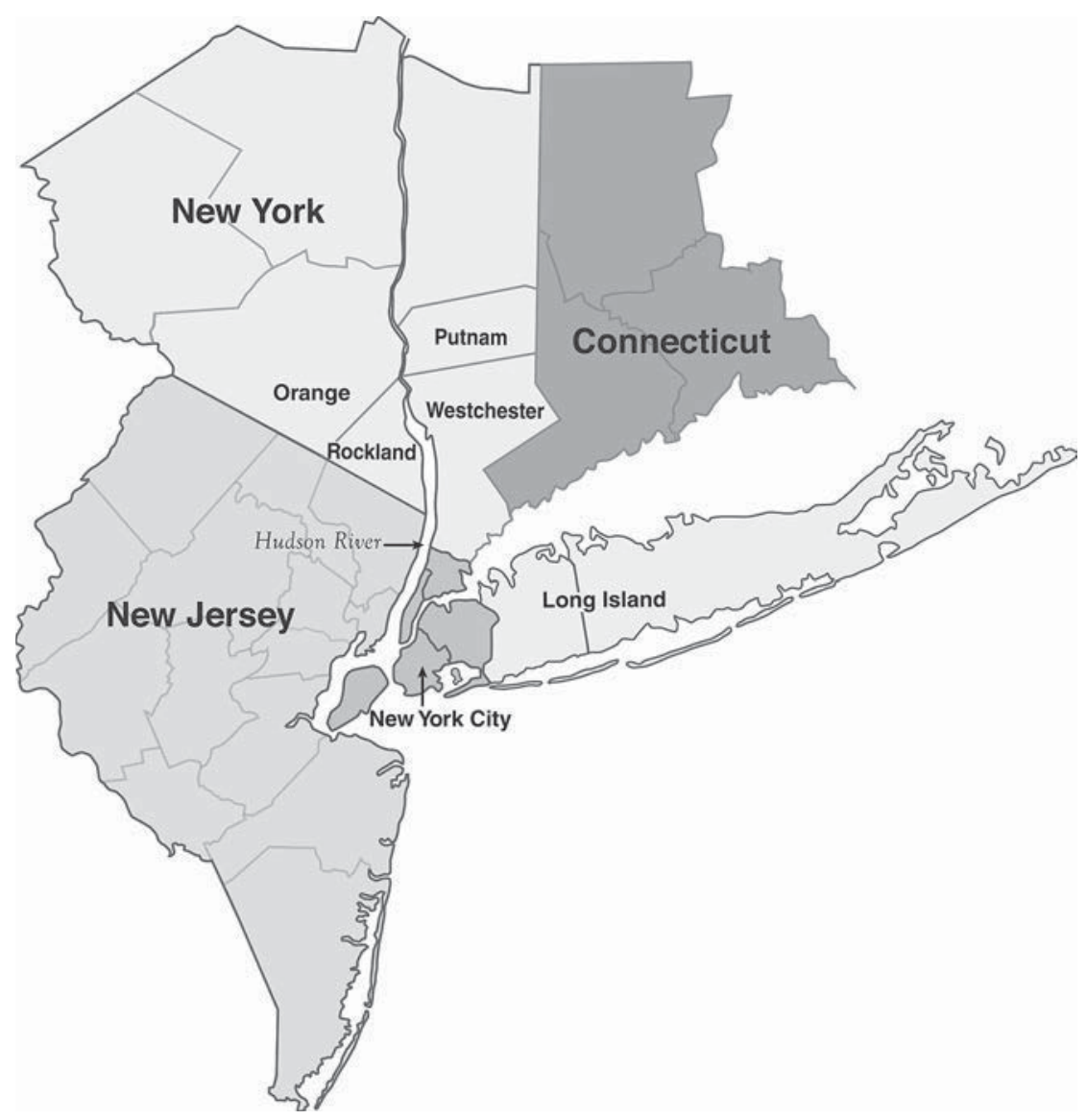

FIGURE G.1 Above: The tristate New York metropolitan area is home to approximately 22 million people. The I-287 corridor runs across Rockland and Westchester Counties in New York. Source: NYCRuss, "Regional Plan Association ${ }_{31}$ County Area," http://en.wikipedia.org/wiki/ File:Regional_Plan_Association_3I_County_Area.png. Creative commons license.

FIGURE G.2 Facing page: The east-west I-287 highway includes the Tappan Zee Bridge across the Hudson River. Metro-North provides train service from New York's northern suburbs on the Port Jervis and Pascack Valley Lines to northern New Jersey (west of the river) and on the Hudson, Harlem, and New Haven Lines to Manhattan (east of the river). 


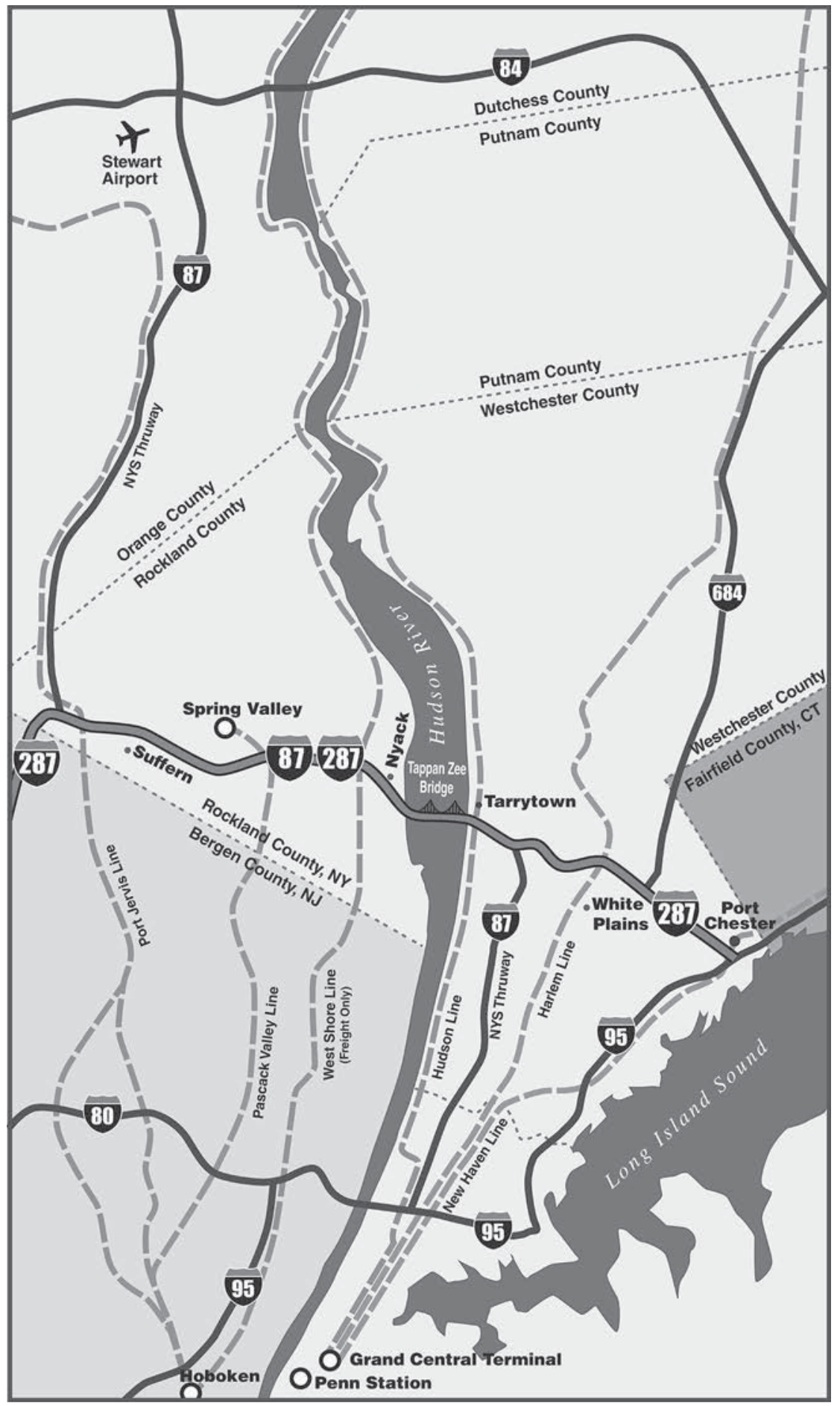




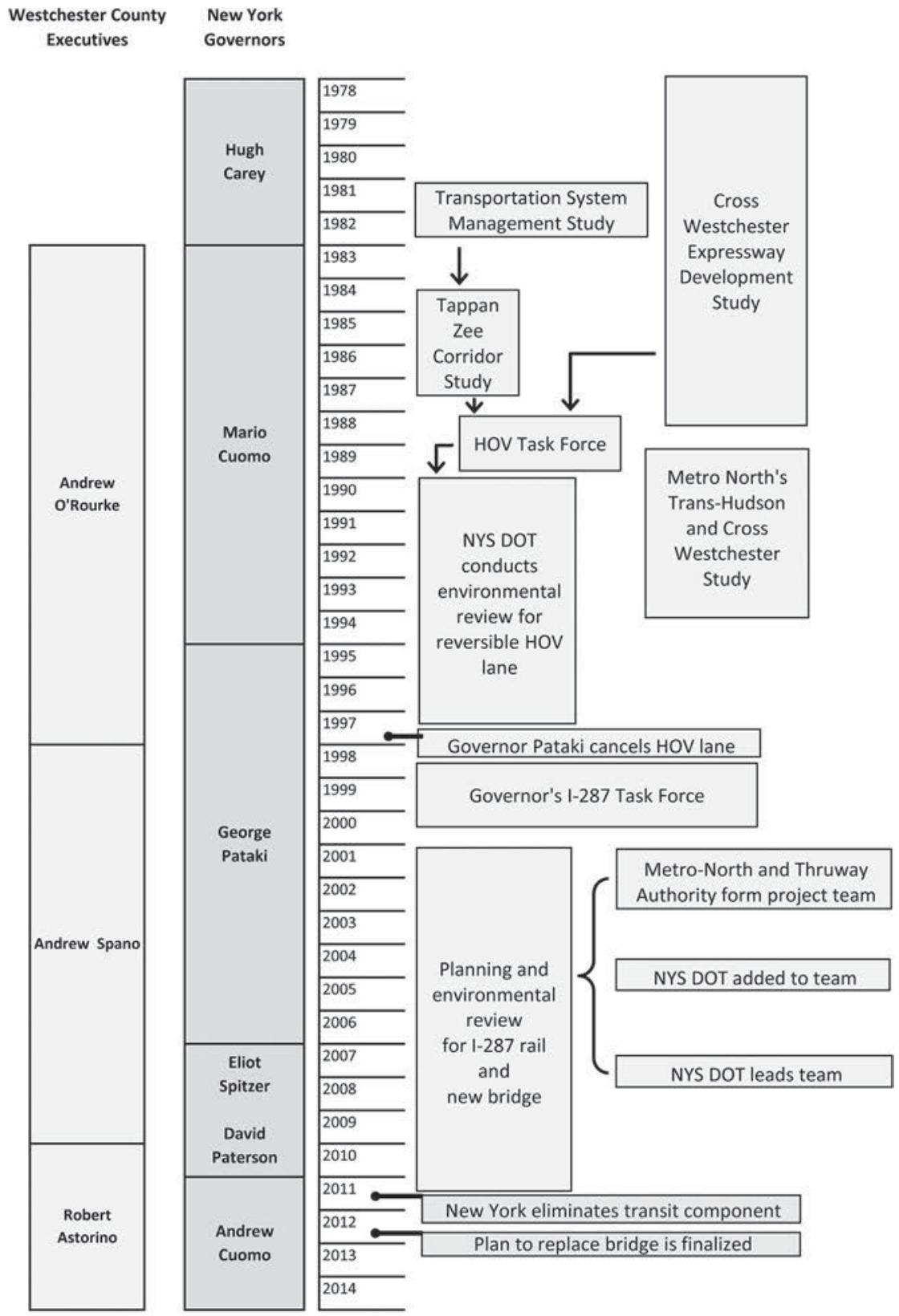

FIGURE G.3 This timeline shows the key events of the I-287/Tappan Zee Bridge megaproject planning process spanning the tenure of six New York governors and three Westchester County executives. 
Politics Across the Hudson 
